\title{
ANTIBACTERIAL ACTIVITY OF ROBUSTA COFFEE (Coffea robusta L.) PEEL EXTRACT AGAINST HUMAN PATHOGENIC BACTERIA
}

\author{
Herlina Rante ${ }^{1 *}$, Subehan ${ }^{2}$, Retno Wulandari ${ }^{3}$, Yayu Mulsiani Evary ${ }^{2}$
}

${ }^{1}$ Laboratory of Microbiology, Faculty of Pharmacy, Hasanuddin University, Makassar-Indonesia

${ }^{2}$ Laboratory of Pharmacognosy and Phytochemistry, Faculty of Pharmacy, Hasanuddin University, Makassar-Indonesia

${ }^{3}$ Faculty of Pharmacy, Hasanuddin University, Makassar-Indonesia

Received - December 19, 2020; Revision - March 26, 2021; Accepted - May 12, 2021

Available Online - September 08, 2021

DOI: http://dx.doi.org/10.18006/2021.9(Spl-2-ICOPMES_2020).S264.S268

\section{KEYWORDS \\ Antibacterial activity \\ Coffee peel \\ TLC-Bioautography \\ Agar diffusion \\ Pathogenic bacterial}

\begin{abstract}
Now in these days infectious diseases seriously affect human health and sometimes these infections might become the cause of human mortality. Most of these infectious diseases are caused by bacteria, viruses, and fungi. Although large numbers of antibiotics are available increasing drug resistance in these microorganisms became a serious matter of concern in the scientific community. There is an urgent need for research on alternate natural products that can manage these pathogenic microorganisms without inducing any resistance. The purpose of this study was to determine the antibacterial activity of Robusta coffee (Coffea robusta L.) fruit peel extract against 5 human pathogenic bacteria i.e. Bacillus subtilis ATCC 6633, Staphylococcus aureus ATCC 25923, Escherichia coli ATCC 25922, Pseudomonas aeruginosa ATCC 27853, and Salmonella thypi NCTC 786. The sample was extracted using the maceration method with methanol as the solvent. The antibacterial activity of fruit peel extract was determined by using the agar diffusion method while the presence of active ingredients was determined by the using TLC-Bioautography assay performed using the mobile phase of $n$-hexane: ethyl acetate $(1: 3)$. The results of the study revealed significant antibacterial activity of coffee peel extract against E. coli and B. subtilis with an inhibition zone of $10.15 \mathrm{~mm}$ and $10.96 \mathrm{~mm}$, respectively. Furthermore, results of the TLC-Bioautography revealed that the compounds at Rf 0.76 inhibit the growth of E. coli and the compounds at Rf 0.27 inhibit the growth of B. subtilis bacteria. These active spots were suspected to be flavonoid and phenolic compounds, respectively but further confirmation detail study is required in the future.
\end{abstract}

* Corresponding author

E-mail: herlinarante@unhas.ac.id (Herlina Rante)

Peer review under responsibility of Journal of Experimental Biology and Agricultural Sciences.

Production and Hosting by Horizon Publisher India [HPI] (http://www.horizonpublisherindia.in/).

All rights reserved.
All the articles published by Journal of Experimental Biology and Agricultural Sciences are licensed under a Creative Commons Attribution-NonCommercial 4.0 International License Based on a work at www.jebas.org.

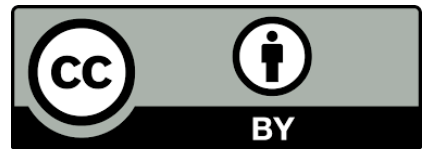




\section{Introduction}

Infectious diseases caused by bacteria are the most common diseases affecting people in developing countries, including Indonesia. Diseases caused by bacteria are usually treated by administering antibiotics while frequent uses of antibiotics in the treatment of these infections bacteria usually caused resistance development against the most commonly used antibiotic. (Frieri et al., 2017). Recently, the global antimicrobial resistance and use surveillance system suggested that bacteria developed resistance against frequently used antibiotics for the treatment of several infections including diarrhea, sepsis, and urinary tract infection, and it revealed the depletion of effective antibiotics. As per the WHO report, more than $90 \%$ of E. coli strains are resistant to the most commonly used antibiotic drug ciprofloxacin that is associated with the treatment of urinary tract infection (WHO, 2020). The problem of antibiotic resistance increasing every year, therefore, it is necessary to research the search of alternative natural substances which have antibacterial properties and can serve as a source of new drugs.

The coffee plant (Coffea sp.) belongs to the family Rubiaceae, which is a tropical plant and widely consumed as a nonalcoholic beverage throughout the world. As per the report of Indonesia Coffee and Cocoa Research Institute (ICRI), Indonesia is the thirdlargest coffee-producing country in the world after Brazil and Vietnam (Radydjencole, 2011). However, the large amount of coffee production is not balanced with appropriate waste processing especially in the case of peel and the leaves of the coffee plant. So far, the waste from the peel of the coffee has been used by farmers as animal feed but as per the chemical composition of the coffee cherries, many alternative uses can be generated from the peel of the coffee plant (Pujiyanto, 2007).

The ability to inhibit the growth of pathogenic bacteria can be influenced by the structure of secondary metabolites contained in plants. Widyotomo \& Sri (2007) reported the presence of several secondary metabolites such as 1,3,7-Trimethylpurine-2,6-dione (caffeine) and polyphenol compounds from the coffee peel which have antimicrobial properties. Further, research conducted by Ridwan (2018) also reports the presence of flavonoids and polyphenols from the coffee peel and that shows antibacterial activity against $S$. aureus and E. coli.

Among the secondary metabolite, phenolic acids have strong antibacterial activity against Gram-positive bacteria. These phenolic compounds having different alkyl chains of hydroxyl groups that can form complexes with bacterial cell membrane proteins. Further, phenolic compounds like gallotannins bind to the membrane protein and inactivate these membrane bounds proteins of bacteria. While flavonoids have multiple cellular targets which inhibit the formation of nucleic acid, attachment, and biofilm formation of bacteria and sometimes disturbed the functioning of the cytoplasmic membrane such as permeability of the membrane, and energy metabolism. (Yixie et al., 2015; Rempe et al., 2017). A study on 2',4'-dihydroxylation of B ring and 5,7dihydroxylation of A ring in the flavone was affecting the activity of the compound against methicillin resistance bacteria (Cushnie \& Lamb, 2005; Patra, 2012). The purpose of this study was to evaluate the antibacterial activity of the coffee peel extract against the selected pathogenic bacteria using the TLC bioautography and agar diffusion method.

\section{Materials and Methods}

The materials used in this research included nutrient agar (Merck) as the medium, DMSO (Merck), methanol (Merck), n-hexane (Merck), ethyl acetate (Merck), paper disk, TLC plate (Merck), $\mathrm{AlCl}_{3}, \mathrm{FeCl}_{3}$, Lieberman Bouchard, and dragendorff reagents. All materials are pro-analytical grade.

\subsection{Sample preparation}

Coffee peel sample was collected from the Robusta Coffee Factory, Majannang Village Gowa Regency. The sample was air dried, mashed and sieved using a no. 18 mesh.

\subsection{Extraction}

The sample was extracted with the maceration method using methanol as the solvent. The obtained extract was filtered and concentrated using a rotary evaporator until a thick extract was obtained (Vijay et al., 2012).

\subsection{Antibacterial Activity Assessment}

The antibacterial assay was carried out by using the disk diffusion method on nutrient agar (NA). The methanol extract with a concentration of $2 \mathrm{mg} / 20 \mathrm{~mL}$ was added to paper discs and these paper discs were left to dry. Dried paper discs were inoculated on the nutrient agar plates pre-inoculated with B. subtilis ATCC 6633, S. aureus ATCC 25923, E. coli ATCC 25922, P. aeruginosa ATCC 27853, and $S$. typhi NCTC 786 bacterial culture, and these cultural plates were incubated at $37^{\circ} \mathrm{C}$ for $24 \mathrm{hrs}$. DMSO was used as a negative control. The diameter of the inhibition zone was measured after 24 hrs of incubation (Somayeh et al., 2014; Denis et al., 2019).

\subsection{Contact Bioautography Assay}

The methanol extract of Robusta coffee was spotted on a TLC plate (silica gel plate Merck 60 F254) then eluted with a mixture of n-hexane: ethyl acetate $(1: 3 \mathrm{v} / \mathrm{v})$ as the mobile phase. The antibacterial activity of active spots was detected using TLC bioautography method (Pandey et al., 2004) on MHA media using the same test microorganism on the previews method and then the plate was left in the refrigerator for 30 minutes for pre-incubation. 
After 30 minutes, the TLC was removed from the plate and incubated again for 24 hours at $37^{\circ} \mathrm{C}$, and then the inhibition zone was observed. The inhibition zone was observed and matched with the Rf value of the TLC plate (Demetrio et al., 2016).

\section{Results and Discussion}

This research was used to evaluate the antibacterial activity of Robusta coffee fruit peel extract against pathogenic microorganisms (Figure 1). Robusta coffee fruit extract was prepared by the maceration method using methanol as a solvent, and the obtained amount of extract was $4.27 \%$. The obtained methanol extract was tested against $E$. coli, $S$. typhi, P. aeruginosa, S.aureus, and B.subtilis by agar diffusion method (Brooks et al., 2005). The antibacterial compound will diffuse into the solid media and inhibits bacterial growth, which is indicated by the formation of a clear area which is known as a zone of inhibition around the disc paper. Methanol extract exhibit antibacterial activity against the tested four bacteria i.e. E.coli, S.aureus, B.subtilis, S.typhi at a concentration of $2 \mathrm{mg} /$ disc while it did not show any inhibitory activity against $P$. aeruginosa (Table 1 ).

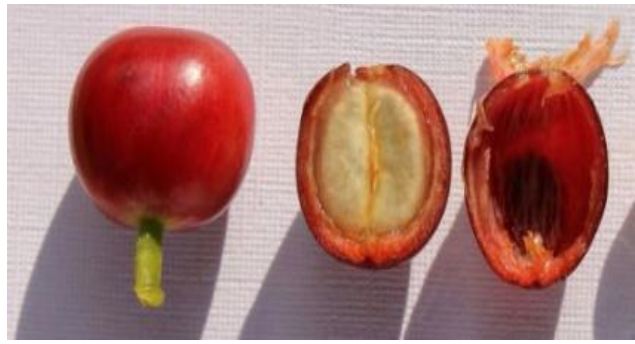

Figure 1 Coffee peel from CoffearobustaL

The active compound of the extract was detected by contact bioautography method using n-hexane: ethyl acetate (1:3) as the eluent and silica $\mathrm{GF}_{254}$ as the stationary phase and then observed under UV $366 \mathrm{~nm}$ and UV $254 \mathrm{~nm}$ wavelength (Figure 2). The results of the TLC-bioautography revealed antibacterial activity of Robusta coffee peel extract against $E$. coli with a $\mathrm{Rf}$ value of 0.76 and B. subtilis with a $\mathrm{Rf}$ value of 0.27 . However, for S.aureus and $S$. typhi the inhibition zone was formed at the initial spotting point of the medium containing (figure 3 ). The polarity properties of silica gel F254 plate bind tightly the polar compounds making them stay on the initial spotting point and not being eluted and this might be a reason that the active compounds at the initial spotting point showed a clear zone as polar compounds (Arcana \& Anubha, 2011).
Identification of chemical compounds was carried out to determine the classes of the compounds contained in the coffee peel extract using TLC plates with sprayed reagents. The result showed that the methanol extract of coffee peel extract had a visible mark of the dark blue spot after being sprayed with $\mathrm{FeCl} 3$ reagents which characterized the presence of the phenolic compound, while the marked with light blue spot after being sprayed with citroboric reagents and observed under UV $366 \mathrm{~nm}$ suggested the presence of the flavonoid compound. Along with this, after spraying the Lieberman Bouchard reagents, the spots on the TLC plate turn to



(a)

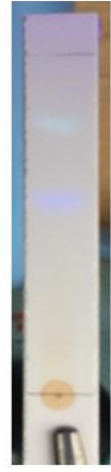

(b)

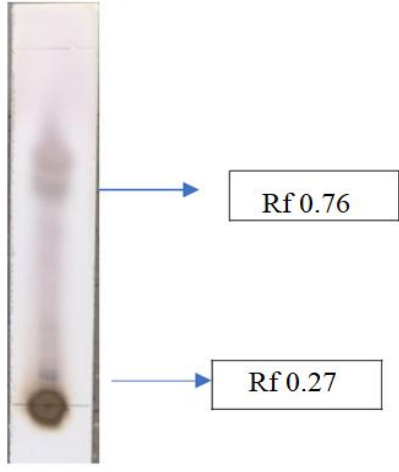

(c)
Figure 2 Chromatogram of methanol extract (a) UV Appearance 254 $\mathrm{nm}$, (b) UV Appearance $366 \mathrm{~nm}$ and (c) After spraying $\mathrm{H}_{2} \mathrm{SO}_{4}$

brown which indicated the existence of terpene compounds in the extract. The active spot on the TLC-bioautography test that inhibits E. coli was located at $\mathrm{Rf} 0.76$ while the B. subtilis spot was located on $\operatorname{Rf} 0.27$ and the active ingredients associated with these spots could be flavonoid and phenolic compounds respectively (Choma IM, Edyta, 2011; Tiwari, 2011; Elzbieta et al., 2016).

The possible mechanism of antibacterial activities of flavonoid compounds was the formation of complex compounds with extracellular proteins which inhibiting cell membrane function and energy metabolism by inhibiting the use of oxygen by bacteria (Cushnie \& Lamb, 2005). While phenolic compounds denaturing the bacterial cell proteins and inhibit the multiplication of bacterial cells. The membrane bonds formed between phenol and protein damaged the protein structure. Further, the hydrogen bonds will affect the permeability of the cell wall and cytoplasmic membrane because both are composed of proteins. The disturbed permeability of the cell wall and cytoplasmic membrane can cause an imbalance of macromolecules and ions in the cell so that the cell becomes lysis (Cowan, 1999).

Table 1 Antibacterial activity of methanol extract against five different test bacteria.

\begin{tabular}{|ccccccc|}
\hline & \multicolumn{4}{c}{ Zone of Inhibition diameters (mm) } \\
& E.coli & S.aureus & S.thypi & B.subtilis & P.aeruginosa & DMSO \\
\hline Methanol extract & $10.15 \pm 1.02$ & $9.70 \pm 0.85$ & $8.96 \pm 0.29$ & $10.96 \pm 1.00$ & $6.00 \pm 0.92$ & $5.95 \pm 0.90$ \\
\hline
\end{tabular}

Journal of Experimental Biology and Agricultural Sciences http://www.jebas.org 

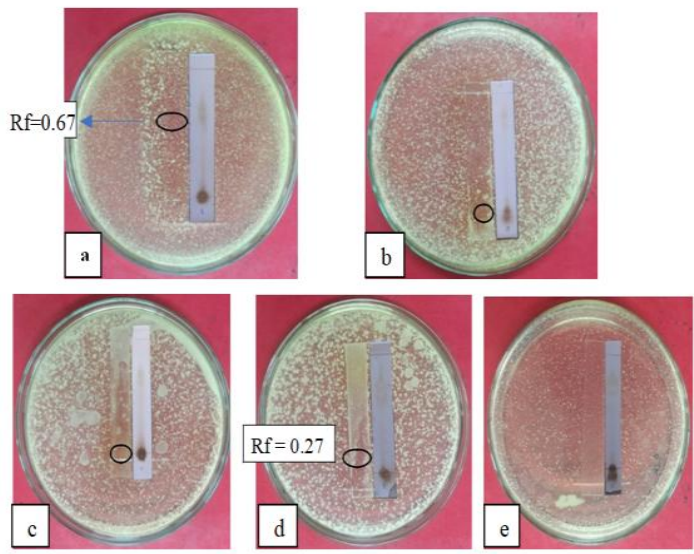

Figure 3 TLC-Bioautography of the extract against (a) E. coli, (b) S. aureus, (c) S. thypi, (d) B. subtilis, and (e) P. aeruginosa

\section{Conclusion}

The methanol extract of Robusta coffee peel exhibited antibacterial activity against of E.coli, S.aureus, S. typhi, and B.subtilis bacteria. Further, the TLC-bioautography test revealed that the methanol extract has antibacterial activity against E.coli with $\mathrm{Rf} 0.76$ and $B$. subtilis with $\mathrm{Rf} 0.27$ and it was suspected the presence of flavonoids and phenolic compounds, further detailed studies required for establish the presence of these active ingredients (Figure 4).

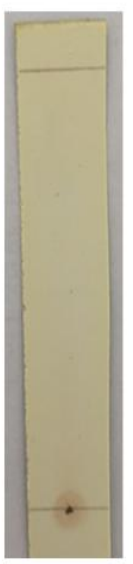

(a)

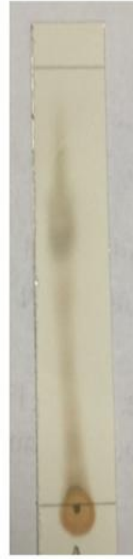

(b)

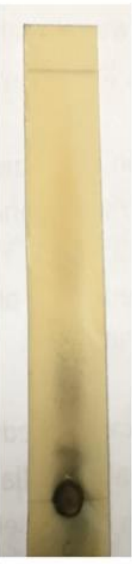

(c)

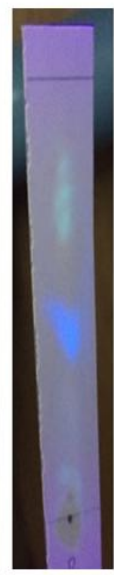

(d)

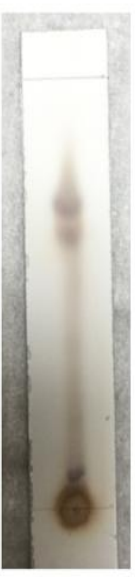

(e)
Figure 4 Identification of chemical compound (a) Dragendorff reagent, (b) $\mathrm{LB}$ reagent, (c) $\mathrm{FeCl}_{3}$ reagent, (d) cytoborate reagent and (e) Vanillin $\mathrm{H}_{2} \mathrm{SO}_{4}$ reagent

\section{Acknowledgement}

The authors acknowledge all the members of the Pharmacy Faculty for facilitating instruments needed for this research.

\section{Conflict of Interest}

The authors declare that there is no conflict of interest in this manuscript

\section{References}

Arcana AB, Anubha K (2011) An Overview On Thin Layer Chromatography. International Journal Of Pharmaceutical Sciences and Research 2(2): 256-267 http://dx.doi.org/10.13040/IJPSR.0975-8232.2(2).256-67.

Brooks GL, Butel JS, Morse SA (2005) Mikrobiologi Kedokteran Ed. 23.Jakarta: Salemba Medika.

Choma IM, Edyta MG (2011) Bioautography detection in thinlayer chromatography. Journal of Chromatography A. 1218(19): 2684-2691. doi: 10.1016/j.chroma.2010.12.069.

Cowan MM (1999) Plant Product as Antimicrobial Agents. Clinical Microbiology Reviews 12 (4): 564-582.

Cushnie TP, Lamb AJ (2005) Amtimicrobial Activity of Flavonoids. International Journal of Antimicrobial Agents 26(5): 343-356.

Demetrio L.VJr, Juliana JMP, Esperanza CC, Windell LR (2016) Thin Layer Chromatography-Bioautography and Gas Chromatography-Mass Spectrometry of Antimicrobial Leaf Extracts from Philippine Piper betle L. against Multidrug-Resistant Bacteria. Evidence-Based Complementary and Alternative Medicine http://dx.doi.org/10.1155/2016/4976791.

Denis Z, Golda LS, Josepha FT, Merveille OT, Jules-CAN (2019) In Vitro and In Vivo Anti-Salmonella Evaluation of Pectin Extracts and Hydrolysates from "Cas Mango" (Spondias dulcis). EvidenceBased Complementary and Alternative Medicine 19:3578402. doi: $10.1155 / 2019 / 3578402$.

Elzbieta M, Anna W, Roman P, Robert R, Beata P, Helena D (2016) The New TLC Method for Separation and Determination of Multicomponent Mixtures of Plant Extracts. Journal of Analytical Methods in Chemistry http://dx.doi.org/10.1155/2016/1813581.

Frieri M, Kumar K, Boutin A (2017) Antibiotic resistance. Journal of Infection and Public Health 10(4): 369-378.

Pandey B, Ghimire P, Agrawal VP (2004) Studies on the antibacterial activity of the Actinomycetes isolated from the Khumbu Region of Nepal. Antimicrobial resistance surveillance available at https://citeseerx.ist.psu.edu/viewdoc/download?doi=10.1.1.506.6811 $\&$ rep=rep $1 \&$ type $=$ pdf. 
Patra AK (2012) An Overview of Antimicrobial Properties of Different Classes of Phytochemicals. In: Patra A (Eds) Dietary Phytochemicals and Microbes. Springer, Dordrecht. https://doi.org/10.1007/978-94-007-3926-0_1.

Pujiyanto (2007) Pemanfaatan Kulit Buah Kopi dan Bahan Mineral SebagaiAmelioran Tanah Alami. Pelita Perkebunan 23:159-172.

Radydjencole (2011) Indonesia Penghasil Kopi Terbesar ke-3 Dunia. Diuploadtanggal 24 Oktober2011 available at http://forum.detik.com/indonesia-penghasil-kopi-terbesar-ke-3dunia-t292411.html.

Rempe CS, Burris KP, Lenaghan SC, Stewart Jr CN (2017) The Potential of Systems Biology to Discover Antibacterial Mechanisms of Plant Phenolics. Frontiers in Microbiology 8:422. doi: 10.3389/fmicb.2017.00422.

Ridwan MH (2018)Aktivitas Daya Hambat Limbah Daging Buah Kopi Robusta (Coffea robustaL.) Aceh terhadap Bakteri S.aureus dan E.coli. Jurnal Kesehatan 9(1): 93-98.

Somayeh R, Mahmood AA, Salmah $\quad$ BI, Pouya $\quad H \quad$ (2014)
Antibacterial Activity of Leaf Extracts of Baeckea frutescens against Methicillin-Resistant Staphylococcus aureus Biomed Research International. https://doi.org/10.1155/2014/521287.

Tiwari P (2011) Phytochemical Screening and Extraction: A Review. Internationale Pharmaceutica Sciencia 1 (1): 98-106.

Vijay K, Ankit G, Madhu N (2012) Extraction Methods for Preparation of Bioactive Plant Extracts. Lambert Academic Publishing, Page No. 15-16.

WHO (2020) Antimicrobial Resistance.https://www.who.int/newsroom/fact-sheets/detail/antimicrobial-resistance, accessed on 11 June 2021.

Widyotomo S, Sri M (2007) Kafein: Senyawa Penting Pada Biji Kopi. Warta Pusat Penelitian Kopi dan Kakao Indonesia.

Yixi X, Weijie Y, Feng T, Xiaoqing C, Licheng R (2015) Antibacterial activities of flavonoids: structure-activity relationship and mechanism. Current Medicinal Chemistry 22(1):132-49. doi: 10.2174/0929867321666140916113443. 